\title{
The Entrepreneurship Education Target under the Cultivation Framework of College Talents
}

\author{
Yue Hao \\ College of Business Administration, Jilin Engineering Normal University, Changchun City, China \\ 18792044@qq.com
}

Keywords: Colleges; Entrepreneurship education; Target; Talent cultivation; Curriculum setting

\begin{abstract}
The entrepreneurship education target should be inspected and confirmed from the whole cultivation framework of college talents and also the development and step implementation of the target should be thought combined with the practical life. Under the guidance of the general target of the entrepreneurial quality talents cultivation, social citizens with good entrepreneurship, self-employed people and new-type enterprises should be cultivated hierarchically from low to high. The theoretic characteristic of entrepreneurship education target requires the setting of the college entrepreneurship education curriculum can't be divorced from the whole system framework of talent cultivation and requires this course to strengthen the integration with other courses and combine with the stratified targets of the entrepreneurship education.
\end{abstract}

\section{Introduction}

Currently, since America brings the entrepreneurship education into the whole national education system, Germany puts forward to make colleges become melting pots of entrepreneurs, Japan takes the entrepreneurship education as urgent affairs of social development and India puts forward the self-employment education of colleges, the entrepreneurship education has become an international trend and the basic consensus of the reform development of the world education. In our country, compared with the bustling scene of carrying out college entrepreneurship education, the effect of the entrepreneurship education is far apart from our original desire. Some scholars point out that there is a situation in our college entrepreneurship education that is more forms but fewer contents, more incomes but fewer effects and more tries but fewer advances [1].

\section{The Talent Cultivation Target of the College Entrepreneurship Education}

The General Target of the College Entrepreneurship Education. From the endogeny logic of the college entrepreneurship education, entrepreneurship education is not so much considered as a choice of the college that has to comply with the current social situation but rather as the deepening and transformation of the talent cultivation mode which are made by college in order to comply with the development of the times actively and the further reification of the talent cultivation concept of the quality education and innovation education which are practiced by colleges[2]. That is, college entrepreneurship education is the same with college talent cultivation, the essence of them is the problem to cultivate what kind of talents.

As for the college which takes the talent cultivation as the primary task, the entrepreneurship education is not an add-on activity of the college [3] or isomerism substance but the obligation of the college talent cultivation. The entrepreneurship education which is carried out by the college must run through the overall structure of the college talent cultivation and take it as the carrier to make the entrepreneurship education coordinate and unity with the talent cultivation. That is, entrepreneurship education must be carried out round the basic gist of the talent cultivation. Meanwhile, the correlation between the college entrepreneurship education and talent cultivation means that the entrepreneurship education target should be inspected and confirmed from the whole talent cultivation framework of colleges. Based on this idea and combined with above viewpoints of scholars, this paper considers 
that the target of college entrepreneurship education is to cultivate undergraduates into the talents who possess a certain entrepreneurship quality. And it is also the general target of the college entrepreneurship education which is consistent with the educational policy spirit of our country and integrate with the talent cultivation mission of the higher education.

The Stratification of the Target of the College Entrepreneurship Education. As mentioned above, cultivating undergraduates into the talents who possess a certain entrepreneurship quality is just the general target of the college entrepreneurship education [4]. However, when it is specifically implemented into the entrepreneurship education practice of colleges and the entrepreneurship education is promoted through the specific teaching process, the target must be more clear. That is, combined with the realistic social situation, the type of school, own conditions of students and other factors, the general target is layered in the whole framework of college talent cultivation system. This paper will divide the target of college entrepreneur education into three levels through the vertical dimensionality from the angle of cultivating into what kind of talents, and there are corresponding knowledge, ability, quality and other entrepreneurship requirements in each level ( as shown in Fig. $1)$.

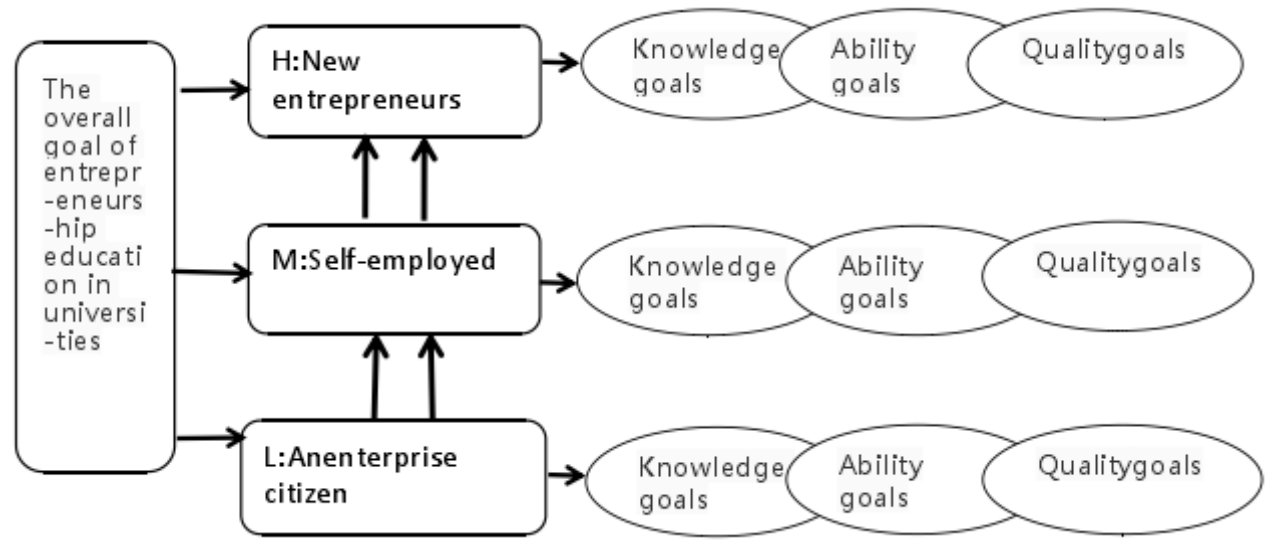

Figure 1. The Stratified Target of the College Entrepreneurship Education

The First Level: Social Citizens with Good Entrepreneurship. The entrepreneurship education target has a very large universality in this level, and it faces all undergraduates and implements the principle of popularization of entrepreneurship. In this level, cultivating social citizens with good entrepreneurship is the main target of the college entrepreneurship education and also the basic target [5].

The Second Level: Self-employed People. Cultivating self-employed people is an important target under the increasingly strained situation of the social current employment situation in our country and it implements the principle of enhancing the entrepreneurship knowledge, entrepreneurship skills and quality education of undergraduates. The achievement of this level target is the development of the entrepreneurship education target of the first level and also the precondition and foundation to achieve the higher level target.

The Third Level: New-type Enterprises. Cultivating new-type entrepreneurs is the supreme ideal and pursuit of the entrepreneurship education in the context of the current society and spontaneously locates at the highest level in the target system of the college entrepreneurship education. The achievement of this target is not the cloud-castle but the achievement of the employment of the highest level based on the achievement of the first and second level of the entrepreneurship education and through the display of the subjective innovation consciousness of entrepreneurs and the good interaction between entrepreneurs and the social relationship [6].

The above hierarchical entrepreneurship education target system is conductive to convert the entrepreneurship education concept into the college education standard or the basic requirement of the teaching and is also conductive to the development of the quality evaluation work of the future college entrepreneurship education. In addition, when the target system of the college entrepreneurship 
education is formulated, the two points should be emphasized: Firstly, adapting to the educators who possess different family backgrounds, different cultural backgrounds, different preference and personalities becomes the demand of the entrepreneur, and the aim of entrepreneurship education cultivation also should increase flexibility, decrease hardness and reflect the aim of individual development. It means that differences among various categories and various level requirements should be reflected. Secondly, according to international and domestic situation and the situation of entrepreneurship education development, universities need to examine existing entrepreneurship education aiming systems in time and adjust or optimize as soon as possible.

\section{The Curriculum Setting of the College Entrepreneurship Education Based on the Stratified Target}

The above analysis for the target of college entrepreneurship education has the important revelatory significance for the discussion of the setting of the entrepreneurship education curriculum. The curriculum of the entrepreneurship education is the carrier of the entrepreneurship education activities which are carried out by colleges and is also the key to achieve the entrepreneurship education target. For example, Japan is regarded as one of the earliest countries to carry out entrepreneurship education. The reason is that Shigeru Fiji had already offered courses about entrepreneurship education at Kobe University in 1938. Achievement of entrepreneurship education in America was remarkable. The important reason is that offered entrepreneurship education courses are plentiful. Statistically, only 50-70 colleges and universities offered courses related to entrepreneurship in 1977. However, the amount reached about 1100 in 1999. At the beginning of 2005, more than 1600 colleges and universities offered entrepreneurship education courses [7-9]. At present, the amount of courses related to entrepreneurship in two-year and four-year universities is more than 5000 [10].

This paper suggests that because of different cultural background and different higher education school model, the entrepreneurship education courses that are learned and imitated from foreign universities. Strictly speaking, is mostly training courses or business courses related market operation or one aspect of entrepreneurship courses. Entrepreneurship education courses belong to an independent system that is different from general education courses and major education courses in universities. The subject penetration has been done not very well, so it is not entrepreneurship education courses referred to in this paper, which is with the aim of cultivating college students' entrepreneurship quality. The above misunderstanding about entrepreneurship education courses always leads to that the so-called entrepreneurship courses that are offered with intensive efforts of universities in our countries is a mere formality. So combined with above relative description, this paper will put forward course setup based on university entrepreneurship education talent cultivation aim within the framework of talent cultivation in universities.

Entrepreneurship Education Courses Setup within the Framework of Talent Cultivation System in Universities. The scholar in our country, Guan Jingzhi divided entrepreneurship education courses into two subsystems. They are theoretical knowledge system and practical skills system. And then major knowledge, entrepreneurship knowledge, major base practice and skills improvement practice, these four models are set below the two subsystems. At last, specific courses are set below the four models. Zhu Jing divided entrepreneurship education courses into three categories. They are entrepreneurship base courses, assisted-related courses and outreach practice courses. Perspectives aiming at entrepreneurship education courses setup are put forward from different point of view by scholars at home and abroad. These perspectives have important referring value for entrepreneurship courses setup in our country. However, if entrepreneurship education courses are set as an independent course system and tied for other courses or completely independent of the original courses system, this problem will be worth discussing. This paper suggests that entrepreneurship education courses setup needs to be 2). Otherwise, there must be a lot of bad consequences. For example, increasing extra study burden of college students, narrowing the free development space for college students or squeezing teaching hours from other courses so that the university's education 
became a business class. Some scholars such as Kourilsky thought that entrepreneurship education should not be dependent on existing schools of business or entrepreneurship courses system. Qualified entrepreneurs who meet the requirements of reality may not be cultivated by education method of one certain curriculum. So entrepreneurship need to rely on courses system in universities, a more broad course content are in favor of cultivation of entrepreneurs(2002).

The Existing Courses need to be Reformed Comprehensively in Universities so that the Fusion can be Strengthened between Entrepreneurship Education Courses and Other Coursed. Content of entrepreneurship education needs to be excavated, developed, enhanced and integrated within offering courses. On the one hand, innovative and creative educational content is excavated for majors, meanwhile, the idea about entrepreneurship need to be integrated and penetrated and innovation consciousness and entrepreneurship knowledge need to be cultivated and enriched in the process of major learning. On the other hand, the method that includes multi-disciplinary complementarity and multi-disciplinary integration need to be adopted to boost entrepreneurship education.

Combing with Hierarchical Objects of Entrepreneurship Education. Entrepreneurship education courses setup pays attention to cultivation for all the college students' entrepreneurship quality, but this not means that this kind of courses setup will neglect students' personalized demand. Universities should add personalized entrepreneurship education courses models into existing courses system included entrepreneurship education factors. If so, universities can achieve their entrepreneurship education aim called various guidance and improvement. As shown in Fig. 2, in the framework of talent cultivation system in universities, entrepreneurship education courses can integrate with two courses systems. They are general education courses system and major education courses system. The talent cultivation aim of these two courses systems is the first hierarchical object, which is to cultivate social citizens possessing good entrepreneurship quality. At the same time, based on existing two courses systems, entrepreneurship education intensive courses model and entrepreneurship education promotion courses model are set to be selected by students aiming to students' personalized demand and actual social development. They are general education courses system, major education courses system and intensive entrepreneurship education courses. Talent cultivating aim of these three courses systems is the second hierarchical object, which is to cultivate social citizens who can seek jobs individually. These four systems, general education courses system, major education courses system, intensive entrepreneurship education courses and promoted entrepreneurship education courses, is the third hierarchical object, which is to cultivate entrepreneurs possessing innovative consciousness and ability.

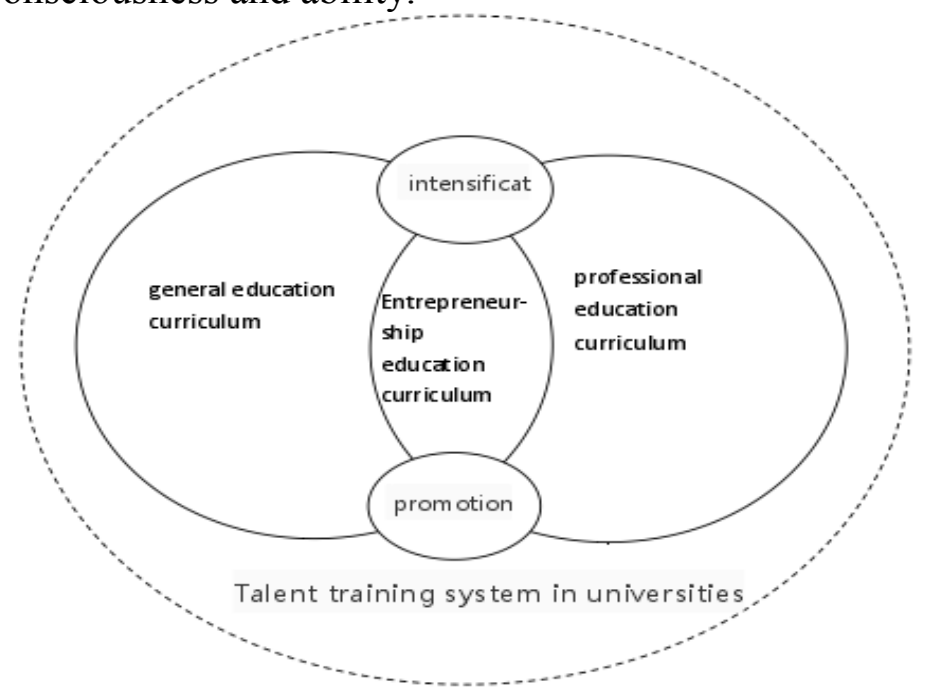

Figure 2. The Cultivation Curriculum System of Entrepreneurial Talents of Colleges 


\section{References}

[1] M.X. Yan: Zhejiang Social Sciences, (2009) No.2, p.84.

[2] I. Jamieson: Schools and Enterprise (Trans CRAC Ballinger, Cambridge 1984)

[3] D.L. Sexton and J.D. Kasarda: The State of the Art of Entrepreneurships (Trans P.W. Kent Publishing Co., Boston 1992)

[4] J.W. Li: Education Profession, (2006) No.18, p.28.

[5] X.J. Ji: Science Times of Entrepreneurship Education in American Universities, 2007-11-27 (3).

[6] B.Y. Huang: China Higher Education Research, (2009) No.7, p.4.

[7] Y.C. Zhou: Joint Times, 2009-10-13 (1).

[8] J. Liang: China Education Daily, 2010-03-27 (2).

[9] G.T. Solomon, S. Duffy and A. Tarabishy: International Journal of Entrepreneurship Education, (2002) No.1, p.1-22.

[10] W.H. Mei: Comparative Education Research, (2008) No.5, p.52-56. 